\title{
Effect and Empirical Models of Nitrogen Uptake Under Different Nitrogen Sources in Dieffenbachia amoena
}

\author{
Silvia Jiménez Becker ${ }^{1}$ and Maria Teresa Lao \\ Almeria University, Vegetable Production, Ctra. de Sacramento, Almería, \\ Almería 04120, Spain
}

\section{Mari Luz Segura \\ Instituto Investigación y Formación Producción Agraría, Departament of Horticulture, Almería, Spain}

Additional index words. ammonium, closed system, deficit pressure vapor, leaf area index, radiation, temperature

\begin{abstract}
Adjusting fertility programs according to peak demand periods will help prevent periodic nutrient disorders during crop growth, allowing enhanced use efficiency of water and fertilization. The objectives of this article were to investigate 1 ) the evolution of the changes in the concentration of nitrate and ammonium in the recycled solution with different $\mathrm{N}-\mathrm{NO}_{3}{ }^{-} / \mathrm{N}-\mathrm{NH}_{4}{ }^{+}$ratios; 2$)$ the influence of the $\mathrm{N}$ form supply $\left(\mathrm{N}_{-} \mathrm{NO}_{3}{ }^{-}\right.$or $\mathrm{N}-\mathrm{NH}_{4}^{+}$) on the nitrogen uptake, the nitrogen:water uptake ratio, and nitrogen use and uptake efficiency; and 3 ) the development of empirical models that would allow the prediction of nitrogen nutritional needs of Dieffenbachia amoena to increase the $N$ use efficiency in a recycled system. To achieve these aims, $N$ uptake has been correlated to climate parameters such as temperature, vapor pressure deficit and global radiation, and growth parameters such as leaf area index. The trial was carried out with Dieffenbachia amoena plants growing in a recycled system with expanded clay as substrate. The crop was placed in an INSOLE (Buried Solar Greenhouse), the plants being supplied with equal amounts of $\mathrm{N}$, differing in the percentage of the $\mathrm{N}$ form applied $\left(\mathrm{NO}_{3}^{-}: \mathrm{NH}_{4}^{+}\right)$: TA (100:0), TB (50:50), and TC (0:100). The nitrogen form generated important changes in the $\mathrm{pH}$ and nitrate and ammonium concentration in nutritive solution during the recirculating solution. In $\mathrm{N}_{-} \mathrm{NO}_{3}{ }^{-}$treatment, $\mathrm{pH}$ increased and nitrate concentration showed a tendency to drop slightly. $\mathrm{N}_{-} \mathrm{NH}_{4}{ }^{+}$treatment showed an abrupt $\mathrm{N}-\mathrm{NH}_{4}{ }^{+}$ concentration decrease, and $\mathrm{N}^{-\mathrm{NO}_{3}}{ }^{-}$concentration increased along with a $\mathbf{p H}$ drop. Also, the nitrogen form applied to the Dieffenbachia amoena crop affects nitrogen uptake. Nitrogen uptake rates and nitrogen uptake concentration were higher in the plants supplied with $\mathrm{N}-\mathrm{NH}_{4}{ }^{+}$or $\mathrm{NO}_{3}{ }^{-}+\mathrm{NH}_{4}{ }^{+}$than in the plants provided with $\mathrm{N}-\mathrm{NO}_{3}{ }^{-}$ alone. The supply of a combination of 50:50 $\mathrm{NO}_{3}{ }^{-}+\mathrm{NH}_{4}{ }^{+}$improved the $\mathrm{N}$ use efficiency. The study also indicated the possibility of predicting the $N$ uptake rate and $N$ uptake concentration using the proposed models.
\end{abstract}

The analysis of current practices reveals a dual approach for controlling plant nutrition, inductive (a posteriori) and deductive (a priori) regulations. The inductive regulation is based on a purely technological breakthrough and it operates rapidly, whereas the deductive regulation is potentially ideal to optimize the control of greenhouse crop mineral nutrition, it is based on the knowledge of plant responses to varying its environment, and it requires models (Le Bot et al., 1998). The models that have been developed fall into two general categories: mechanistic and empirical. Mechanistic models seek to explain how observed phenomena have happened. This approach requires specific

Received for publication 26 July 2007. Accepted for publication 16 Oct. 2007.

${ }^{1}$ To whom reprint requests should be addressed; e-mail sbecker@ual.es knowledge and a mathematical description of the underlying processes (Rengel, 1993). Examples of these models are those that describe the uptake kinetics of ions in relation to concentration at the root surface with the Michaelis-Menten function. On the other hand, empirical models attempt to describe observed phenomena without hypothesizing how they happen (Rengel, 1993). Such models are most often statistical ones. A good compromise is often achieved by selecting models on both extremes of the empiricalmechanistic scale, i.e., empirical models with some mechanistic assumptions (Pardossi et al., 2004). The list of factors (input or independent variables) assumed to influence crop mineral relations such as environmental conditions and water uptake can be regarded as a mechanistic assumption in empirical models for nutrient uptake (Pardossi et al., 2004). Some examples of these models are citied by Brun and Chazelle (1996), Feller and Fink (2002), Kläring et al. (1997), Pardossi et al. (2004), and Zerche et al. (2002).

Both $\mathrm{N}-\mathrm{NH}_{4}{ }^{+}$and $\mathrm{N}-\mathrm{NO}_{3}{ }^{-}$are important nitrogen sources for plant growth (Marschner, 1995). Most plants can use either, or both, ammonium and nitrate, and the effects of the applied $\mathrm{N}$ form depend on the ontogenic development of the plant, the plant species (Bernstein et al., 2005), solution $\mathrm{pH}$, and solution temperature (Wen et al., 2000). In general, plants better adapted to acidic soil conditions seem to prefer ammonium, whereas those adapted to alkaline soils prefer nitrate (Hahne and Schuch, 2006). Dieffenbachia amoena 'Tropic Snow' responds better to mixed $\mathrm{N}$ nutrition (Jiménez and Lao, 2005). Therefore, to prevent nutrient disturbances and to optimize growth in closed hydroponics systems, specific knowledge is required for each particular plant species concerning its response to the ratio $\mathrm{N}-\mathrm{NH}_{4}{ }^{+} /$ $\mathrm{N}$-total supplied through the nutrient solution (Savvas et al., 2006).

The objectives of this article were to investigate: 1) the evolution of the changes in the concentration of nitrate and ammonium in the recycled solution with different $\mathrm{N}$ $\mathrm{NO}_{3}{ }^{-} / \mathrm{N}-\mathrm{NH}_{4}{ }^{+}$ratios; 2) the influence of the $\mathrm{N}$ form supply $\left(\mathrm{N}-\mathrm{NO}_{3}{ }^{-}\right.$or $\left.\mathrm{N}-\mathrm{NH}_{4}{ }^{+}\right)$on the nitrogen uptake, the nitrogen:water uptake ratio, and nitrogen use efficiency; and 3) the development of empirical models that allow the prediction of nitrogen nutritional needs of Dieffenbachia amoena to increase the $\mathrm{N}$ use efficiency in a recycled system. To achieve these aims, $\mathrm{N}$ uptake has been correlated to climate parameters such as temperature $(\mathrm{T})$, vapor pressure deficit (VPD) and global radiation $(\mathrm{Rg})$, and growth parameters such as leaf area index (LAI).

\section{Materials and Methods}

Plant growth environment and irrigation systems. Trials were carried out in an INSOLE (Buried Solar Greenhouse) with zenith ventilation and a relative humidity and temperature control. The plant density was 3.2 plants $/ \mathrm{m}^{2}$. Single plants are grown in $17-\mathrm{cm}$ diameter pots and the substrate used was expanded clay ( 3 to $8 \mathrm{~mm}$ ). The first trial was conducted from 10 Nov. 2000 to 9 June 2001, $200 \mathrm{~d}$ after transplanting (DAT), and the second trial was carried out from $19 \mathrm{Dec}$. 2001 to 13 Aug. 2002, 240 DAT. In both trials, the crops were in a vegetative phenological state. A recycled fertigation system was used. Fertilizer was applied through drip irrigation with one emitter per plant, the drippers were $2 \mathrm{~L} \cdot \mathrm{h}^{-1}$ /emitter, and the irrigation doses and frequency lasted $1 \min 15 \mathrm{~s}$ each $10 \mathrm{~min}$.

Nutritional treatments. The tested treatments were three (TA, TB, and TC), 100:0, 50:50 0:100, respectively, differing in the percentage of the initial $\mathrm{N}$ form applied $(\mathrm{N}$ $\mathrm{NO}_{3}{ }^{-}: \mathrm{N}_{-} \mathrm{NH}_{4}{ }^{+}$). Nutrient solutions used are listed in Table 1. 
Table 1. Concentration ions of the used nutrient solution expressed by $\mathrm{mmol} \cdot \mathrm{L}^{-1}$

\begin{tabular}{lccccccccr}
\hline Treatment & $\mathrm{NO}_{3}^{-}$ & $\mathrm{NH}_{4}^{+}$ & $\mathrm{H}_{2} \mathrm{PO}_{4}^{-}$ & $\mathrm{SO}_{4}{ }^{2-}$ & $\mathrm{Cl}^{-}$ & $\mathrm{K}^{+}$ & $\mathrm{Ca}^{2+}$ & $\mathrm{Mg}^{2+}$ & $\mathrm{Na}^{+}$ \\
\hline TA & 6.0 & 0.0 & 1.2 & 1.0 & 0.6 & 4.0 & 0.9 & 2.4 & 2.0 \\
TB & 3.0 & 3.0 & 1.2 & 4.0 & 0.6 & 4.0 & 0.9 & 2.4 & 2.0 \\
TC & 0.0 & 6.0 & 1.2 & 7.5 & 0.6 & 4.0 & 0.9 & 2.4 & 2.0 \\
\hline
\end{tabular}

Sampling and analyses. Climatic parameters were monitored by means of a climate computer, LCC 900 VOLMATIC (DGTVolmatic). External radiation was measured continuously with a sensor, Q20-B (DGTVolmatic), while temperature and humidity were recorded with RTV-5B sounds. Internal radiation, VPD, and LAI were estimated according to Jiménez et al. (2007).

The water uptake was estimated as the difference between the initial and the final volume in a transparent tube previously calibrated and fixed to the nutritive solution tank. The measurements correspond to an interval of $20 \mathrm{~d}$. To study the $\mathrm{pH}$ and nitrate and ammonium concentration changes of the recycled solution, nutrient solution was collected daily for $20 \mathrm{~d}$ in the winter and summer seasons. The concentrations of $\mathrm{N}^{-\mathrm{NO}_{3}}{ }^{-}$and $\mathrm{N}-\mathrm{NH}_{4}{ }^{+}$were analyzed by spectrophotometry and the $\mathrm{pH}$ was analyzed using a $\mathrm{pH}-$ meter (Ministry of Agriculture and Fishing, 1994).

Estimation of nitrogen uptake, nitrogen uptake concentration, and nitrogen use and uptake efficiency. Net uptake, nitrogen uptake concentration, and nitrogen use efficiency were estimated according to Jiménez et al. (2007).

Percentage of leaf nitrogen. At the end of the experiment, leaves for each replication treatment and plant were collected. The percentage of leaf nitrogen was determined using the Kjedahl method (Ministry of Agriculture and Fishing, 1994).

Experimental design and statistical analysis. The experimental design was unifactorial ( $\mathrm{N}$ form) with three treatments, three replications per treatment, and 20 plants per replication during the two crop cycles. Analysis of data was made using the software packages Excel 7.0 and Statgraphics (StatPoint, Herndon, VA) plus 4.0. Analysis of variance and least significant difference $(P<0.05)$ were made to compare nitrogen uptake between treatments. Simple regressions between nitrogen uptake concentration and nitrogen uptake related to climatic and growth parameters were made to generate models. From all the parameters considered, the one with a higher determination coefficient $\left(\mathrm{R}^{2}\right)$ was selected as the principal parameter. Subsequently, a multiple regression, including considering all the variables one by one, was made. The criterion for accepting a new variable in the model was the increase of $\mathrm{R}^{2}$ and the lowest correlation coefficient between variables (Canavos, 1988).

\section{Results and Discussion}

Climatic and growth parameters during crop growth. Average values of $\mathrm{T}, \mathrm{Rg}$, and VDP for both years are shown in Table 2 .
The climatic parameter ranges were very narrow and in the optimal setting for these species as defined by Jiménez (2001): radiation intensity level 8 to $22 \mu \mathrm{mol} \cdot \mathrm{m}^{-2} \cdot \mathrm{s}^{-1}$

Table 2. Average temperature $\left(\mathrm{T} ;{ }^{\circ} \mathrm{C}\right)$, global radiation $\left(\mathrm{Rg} ; \mathrm{MJ} \cdot \mathrm{m}^{-2} \cdot \mathrm{d}^{-1}\right)$, and vapur pressure deficit (VPD; $\mathrm{kPa}$ ) in the greenhouse during the growth period for both years.

\begin{tabular}{|c|c|c|c|c|c|c|}
\hline \multirow[b]{2}{*}{ DAT } & $\mathrm{Rg}$ & $\overline{V P D}$ & $\mathrm{~T}$ & $\overline{R g}$ & VPD & $\mathrm{T}$ \\
\hline & \multicolumn{3}{|c|}{ First year } & \multicolumn{3}{|c|}{ Second year } \\
\hline 40 & & & & 2.57 & -0.25 & 20.1 \\
\hline 60 & & & & 2.49 & -0.30 & 18.3 \\
\hline 80 & 2.21 & -0.74 & 22.6 & 2.41 & -0.30 & 18.5 \\
\hline 100 & 6.22 & -1.01 & 26.6 & 3.07 & -0.44 & 18.7 \\
\hline 120 & 5.96 & -0.88 & 26.1 & 3.78 & -0.55 & 20.8 \\
\hline 140 & 2.94 & -0.93 & 27.2 & 4.13 & -0.29 & 22.6 \\
\hline 160 & 3.73 & -0.35 & 31.2 & 5.52 & -0.51 & 24.9 \\
\hline 180 & 3.46 & -0.07 & 29.1 & 6.30 & -0.27 & 24.4 \\
\hline 200 & 3.36 & -0.13 & 30.3 & 1.92 & -0.30 & 24.1 \\
\hline 220 & & & & 2.24 & -0.57 & 25.1 \\
\hline 240 & & & & 2.49 & -0.54 & 27.2 \\
\hline
\end{tabular}

$\mathrm{DAT}=$ days after transplanting.
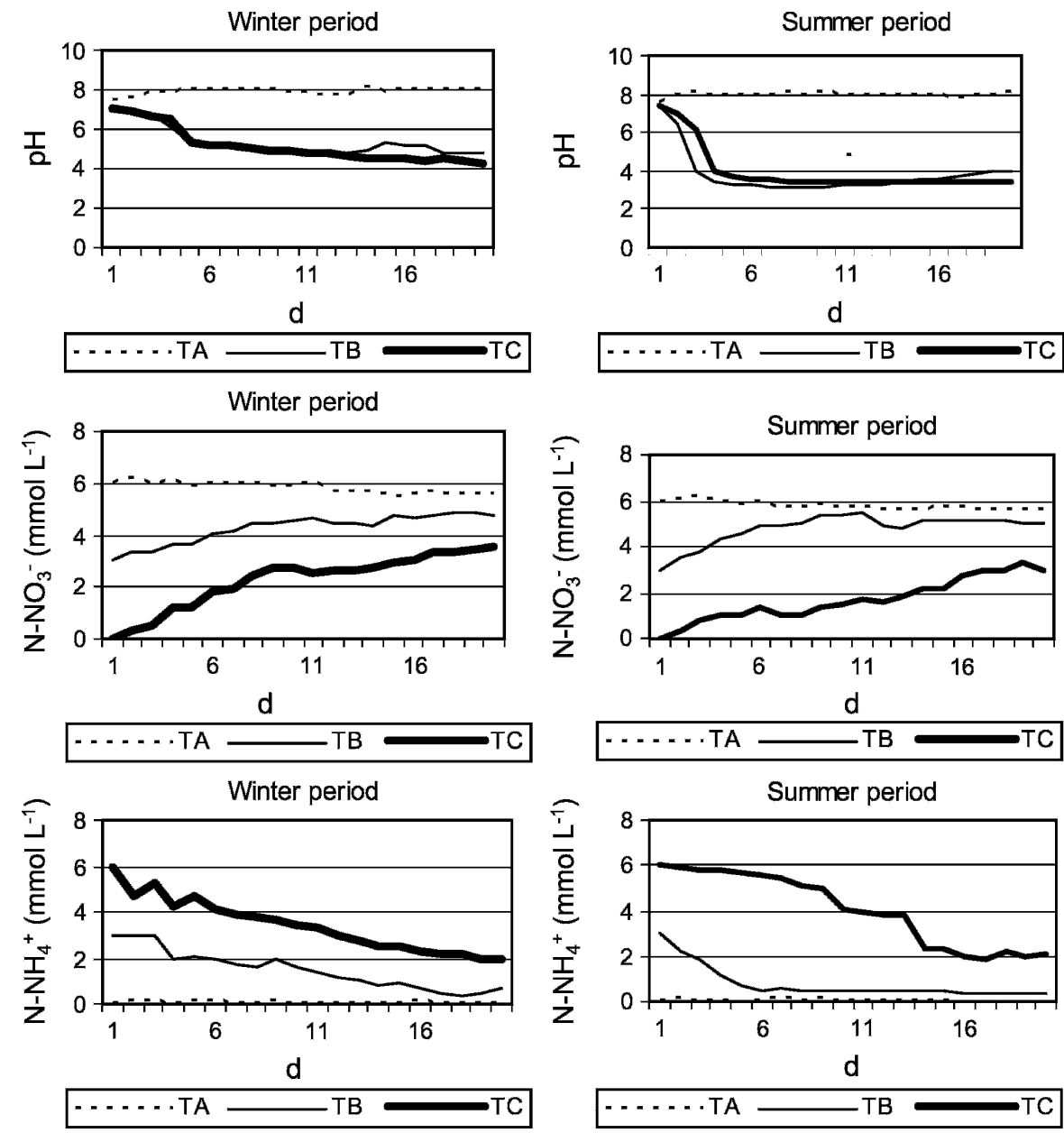

Fig. 1. Changes in $\mathrm{pH}$ and $\mathrm{N}-\mathrm{NO}_{3}{ }^{-}$and $\mathrm{N}-\mathrm{NH}_{4}{ }^{+}$concentration in recycling solution under winter and summer conditions during $20 \mathrm{~d}$. photons, environmental relative humidity $80 \%$ to $85 \%$, and a mild temperature of 13 to $30{ }^{\circ} \mathrm{C}$

Nutrient solution changes during crop. Figure 1 shows changes in $\mathrm{pH}$ and $\mathrm{N}_{-} \mathrm{NO}_{3}{ }^{-}$ and $\mathrm{N}^{-\mathrm{NH}_{4}}{ }^{+}$concentration in recycling solution under winter and summer conditions over $20 \mathrm{~d}$. The nitrogen form generated important modifications in the recirculating solution composition. $\mathrm{pH}$ increased $\approx 1.5$ in TA as a result of the higher anion uptake $\left({\mathrm{N}-\mathrm{NO}_{3}}^{-}\right)$with the consistent $\mathrm{OH}$ cotransport efflux (Van Beusichem et al., 1988), but nitrate concentration did not involve abrupt variations. In winter, $\mathrm{N}_{-} \mathrm{NO}_{3}{ }^{-}$concentration remained constant; in summer conditions, there was a slow decrease resulting from the difference between $\mathrm{N}^{-\mathrm{NO}_{3}}{ }^{-}$and water uptake (Pardossi et al., 2004). Nevertheless, $\mathrm{N}_{-} \mathrm{NH}_{4}{ }^{+}$ concentration in TB and TC showed an abrupt decrease and increase of $\mathrm{N}^{-\mathrm{NO}_{3}}$ concentration together with a $\mathrm{pH}$ drop. Ammonium decrease could be the result of ammonia losses, interaction of substrate, nitrification process, and $\mathrm{N}-\mathrm{NH}_{4}{ }^{+}$uptake. In this case, $\mathrm{pH}$ was always less than 7.5 andat these values - conversion of ammonium to ammonia is negligible (Savvas et al., 2006). As a result of the low cation exchange capacity of the substrate, diminution of 
$\mathrm{N}-\mathrm{NH}_{4}{ }^{+}$resulting from adsorption by expanded clay is also improbable. Ammonium depletion was fundamentally attributed to a nitrification process (Mengel and Kirkby, 2001) and a preferential N-NH${ }_{4}^{+}$uptake accompanied by $\mathrm{H}^{+}$cotransport (Hahne and Schuch, 2006). In the process of nitrification, $\mathrm{N}-\mathrm{NH}_{4}{ }^{+}$is converted into $\mathrm{N}-\mathrm{NO}_{2}{ }^{-}$by ammonium-oxidizing bacteria and $\mathrm{N}^{-} \mathrm{NO}_{2}{ }^{-}$is converted into $\mathrm{N}^{-\mathrm{NO}_{3}}{ }^{-}$by nitrite-oxidizing bacteria. Figure 2 shows the correlation between $\mathrm{N}-\mathrm{NH}_{4}{ }^{+}$and $\mathrm{N}-\mathrm{NO}_{3}{ }^{-}$concentration in recycling solution and indicates that a great part of $\mathrm{N}-\mathrm{NH}_{4}{ }^{+}$was nitrificated. As a result of the effect of temperature, this process occurred more quickly in summer than in winter. Ammonium decrease could also be similar to that observed by Savvas et al. (2006) with a lettuce crop. It seems that Dieffenbachia belongs to the group of species that is capable of absorbing $\mathrm{N}^{-\mathrm{NH}_{4}}{ }^{+}$more rapidly than $\mathrm{N}_{-} \mathrm{NO}_{3}{ }^{-}$from a mixed $\mathrm{N}-\mathrm{NO}_{3}{ }^{-}$/ $\mathrm{NH}_{4}^{+}$source. On the other hand, $\mathrm{pH}$ in $\mathrm{TB}$ and TC was low during most of the cultivation period. Lower $\mathrm{pH}$ levels could restrict the conversion of ${\mathrm{N}-\mathrm{NH}_{4}}_{4}^{+}$to organic $\mathrm{N}$ compounds in the root, thereby increasing the transport of free ammonium to the shoot with detrimental consequences for plant metabolism (Savvas et al., 2006). In this case, this low $\mathrm{pH}$ did not cause damage to the Dieffenbachia crop (data presented by Jiménez and Lao, 2005). It may be that the optimum $\mathrm{pH}$ in the root zone presents significant genotypic differences with regard to the responses of various plant species (Savvas et al., 2003). In a practical sense, the $\mathrm{N}-\mathrm{NH}_{4}{ }^{+}$application may be the $\mathrm{pH}$ regulator, especially in recycling systems (Sonneveld, 2002) but should be monitored more carefully than nutrition with other nitrogen sources because of the

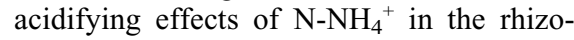
sphere (Stratton et al., 2001).

Effect of nitrogen source on nitrogen uptake. The net daily average nitrogen uptake $\left(\mathrm{N}-\mathrm{NH}_{4}{ }^{+}+\mathrm{N}^{-} \mathrm{NO}_{3}{ }^{-}\right)$was $0.82,1.45$, and 1.54 $\mathrm{mmol} \cdot \mathrm{d}^{-1} /$ plant for TA, TB, and TC, respectively. Uptake levels estimated in this trial are similar to those shown by Cabrera et al. (1995) for a rose crop and lower than those shown by other authors for a tomato crop (Rincón et al., 2004; Terabayashi et al., 2004) and a pepper crop (Bar-Tal et al., 2001). Nitrogen form affected $(P<0.05) \mathrm{N}$ uptake

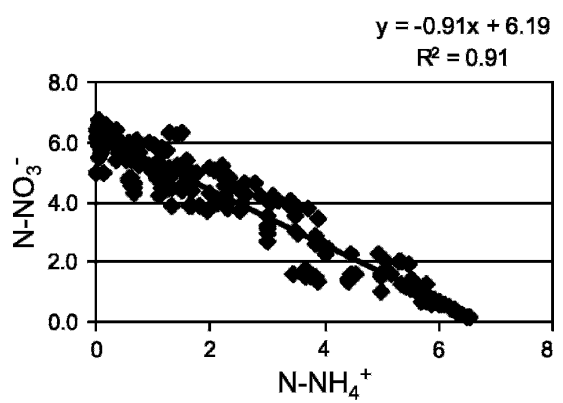

Fig. 2. Simple regression between the nitrate concentration $\left(\mathrm{mmol} \cdot \mathrm{L}^{-1}\right)$ and ammonium concentration $\left(\mathrm{mmol} \cdot \mathrm{L}^{-1}\right)$ in the recycling solution.
(Table 3) significantly; treatments supplied with $\mathrm{N}^{-\mathrm{NH}_{4}+}$ in $\mathrm{TB}$ and $\mathrm{TC}$ have higher average uptake than treatments supplied with $\mathrm{N}-\mathrm{NO}_{3}^{-}$; approximately $43 \%$ and $39 \%$ more. This higher uptake was also related to a higher percentage of nitrogen in leaf (Table 3). Similar results were obtained by Hahne and Schuch (2006) with Prosopis velutina, Bar-Tal et al. (2001) with pepper, and Kim et al. (2002) with pecan. However, Bernstein et al. (2005) observed that nitrogen content in the leaves was unaffected by the fertilization treatments. Epstein and Bloom (2004) consider that $\mathrm{N}_{-} \mathrm{NO}_{3}{ }^{-}$root absorption is involved in a cation cotransport process and is sensitive to the availability of cations, so ${\mathrm{N}-\mathrm{NH}_{4}}^{+}$may either inhibit or stimulate $\mathrm{N}^{-\mathrm{NO}_{3}}{ }^{-}$absorption. In this sense, Wang et al. (2003) observed that the higher nitrogen uptake in $\mathrm{NH}_{4}{ }^{+}-\mathrm{N}$ treatments can be because $\mathrm{NH}_{4}^{+}$uptake acidifies the medium and thus indirectly promotes $\mathrm{N}-\mathrm{NO}_{3}$ uptake. $\mathrm{N}$ use efficiency also increases when ammonium concentration increases; these

results agree with those of Phiri et al. (2003) (Table 3).

Empirical models of nitrogen uptake. To establish models, and as a result of previous results, $\mathrm{TB}$ and $\mathrm{TC}$ are studied together taking into account the $\mathrm{N}-\mathrm{NH}_{4}{ }^{+}$applied. A simple regression between nitrogen uptake and climate and growth parameters was done (Fig. 3). In $\mathrm{N}_{-\mathrm{NO}_{3}}{ }^{-}$treatment, air temperature, LAI, and water uptake were the most correlated parameters with $\mathrm{N}$ uptake $\left(\mathrm{R}^{2}=\right.$ $0.72,0.74$, and 0.67 respectively) (Table 4 ). One of the major factors that directly affects plant growth and, consequently, nutrient demand is root temperature (Economakis and Krulj, 2002). Similarly, Martinez et al. (2004), Economakis and Krulj (2002), and Roca et al. (2003) found an increase of ionic uptake when temperature increased in rose, strawberry and rose crops, respectively. Roca et al. (2003) also observed a positive correlation in summer with VPD and Rg $4 \mathrm{~h}$ before nitrate measurement. In this case, VPD and nutrient uptake did not show good

Table 3. Average of the nitrogen percentage in leaf $\left(\mathrm{g} \cdot \mathrm{g}^{-1}\right)$, leaf area index at the end of the crop (LAI; $\left.\mathrm{m}^{2} \cdot \mathrm{m}^{-2}\right)$, nitrogen uptake $\left(\mathrm{NU} ; \mathrm{mmol} / \mathrm{plant} / \mathrm{d}^{-1}\right)$, water uptake $\left(\mathrm{WU} ; \mathrm{L} / \mathrm{plant} / \mathrm{d}^{-1}\right)$, and nitrogen use efficiency (NUSE; $\mathrm{g} \cdot \mathrm{g}^{-1}$ ).

\begin{tabular}{lccccc}
\hline Treatments & Percent N in leaf & LAI & NU & WU & NUSE \\
\hline TA & $2.46 \pm 0.10 \mathrm{~b}$ & $1.54 \pm 0.30 \mathrm{~b}$ & $0.82 \pm 0.16 \mathrm{~b}$ & $0.11 \pm 0.05 \mathrm{ab}$ & $25.1 \pm 1.1 \mathrm{~b}$ \\
TB & $2.85 \pm 0.15 \mathrm{a}$ & $2.18 \pm 0.20 \mathrm{a}$ & $1.45 \pm 0.20 \mathrm{a}$ & $0.13 \pm 0.05 \mathrm{a}$ & $33.6 \pm 2.1 \mathrm{a}$ \\
TC & $3.13 \pm 0.21 \mathrm{a}$ & $1.73 \pm 0.21 \mathrm{ab}$ & $1.54 \pm 0.15 \mathrm{a}$ & $0.10 \pm 0.04 \mathrm{~b}$ & $35.1 \pm 2.10 \mathrm{a}$ \\
\hline
\end{tabular}

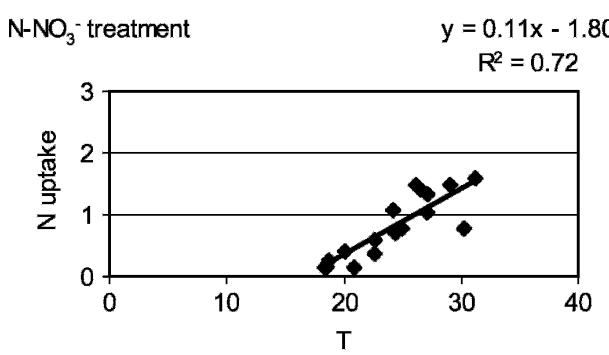

$\mathrm{N}^{-\mathrm{NH}_{4}}{ }^{+}$treatment

$y=12.17 x$

$\mathrm{R}^{2}=0.66$
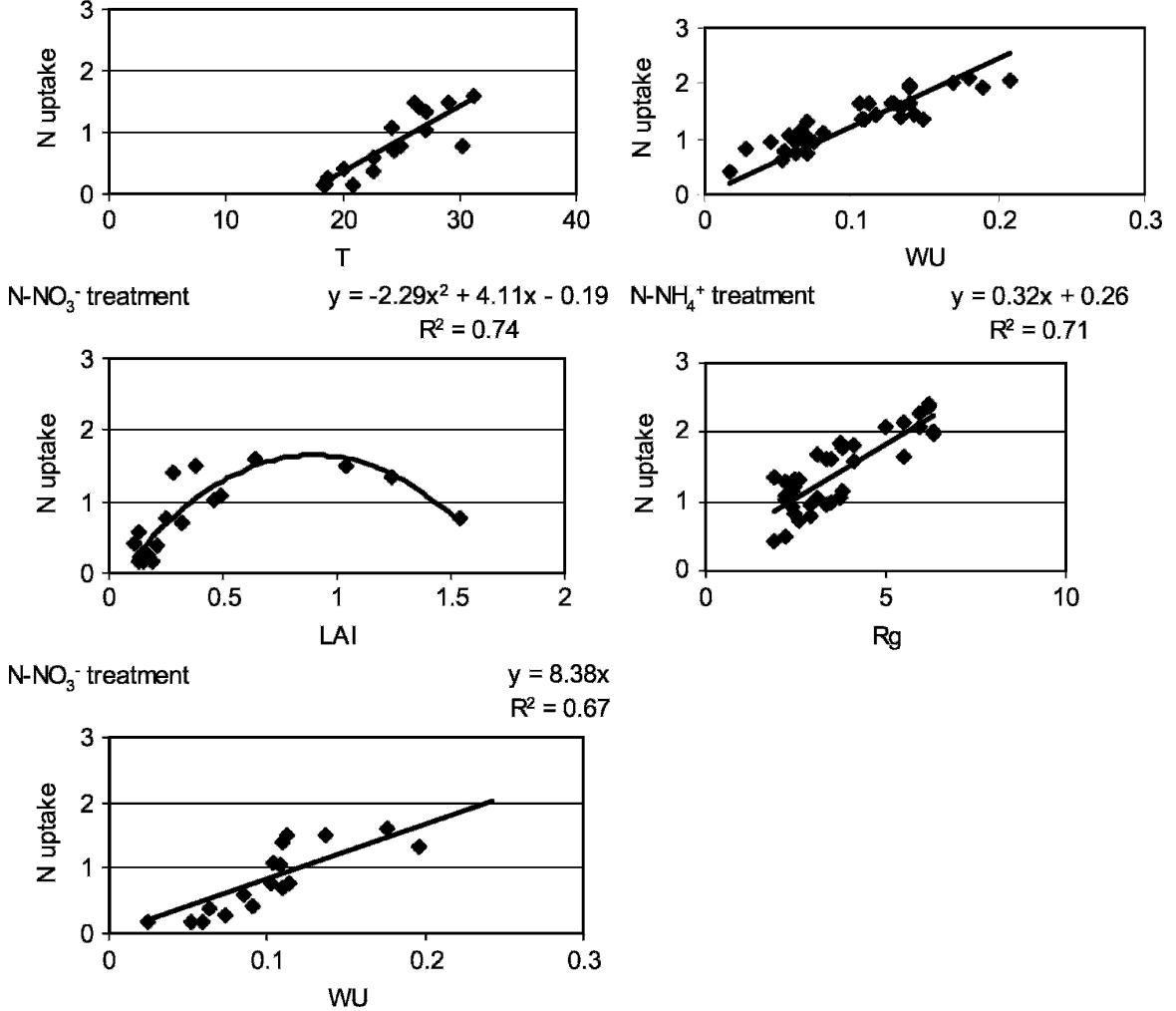

Fig. 3. Simple regression between the nitrogen uptake $\left(\mathrm{mmol} \cdot \mathrm{d}^{-1} / \mathrm{plant}\right)$ and temperature $\left(\mathrm{T} ;{ }^{\circ} \mathrm{C}\right)$, global radiation $\left(\mathrm{Rg} ; \mathrm{MJ} \cdot \mathrm{m}^{-2} \cdot \mathrm{d}^{-1}\right)$, water uptake $\left(\mathrm{WU} ; \mathrm{L} \cdot \mathrm{d}^{-1} / \mathrm{plant}\right)$, and leaf area index $\left(\mathrm{LAI} ; \mathrm{m}^{2} \cdot \mathrm{m}^{-2}\right)$ in treatments with and without ammonium $(P<0.05)$. 
Table 4. Simple correlation between nitrogen uptake (mmol. $\left.\mathrm{d}^{-1} / \mathrm{plant}\right)$ and temperature $\left(\mathrm{T} ;{ }^{\circ} \mathrm{C}\right)$, global radiation $\left(\mathrm{Rg} ; \mathrm{MJ} \cdot \mathrm{m}^{-2} \cdot \mathrm{d}^{-1}\right)$, water uptake (WU; $\mathrm{L} \cdot \mathrm{d}^{-1} /$ plant), vapor pressure deficit (VPD; $\left.\mathrm{kPa}\right)$, and leaf area index $\left(\mathrm{LAI} ; \mathrm{m}^{2} \cdot \mathrm{m}^{-2}\right)$ in TA.

\begin{tabular}{llc}
\hline Parameters & \multicolumn{1}{c}{ Correlation model } & Correlation coefficient $\left(\mathrm{R}^{2}\right)$ \\
\hline Temperature & $\mathrm{NU}=0.11 * \mathrm{~T}-1.80$ & 0.72 \\
Global radiation & $\mathrm{NU}=0.11 * \mathrm{Rg}+0.41$ & 0.09 \\
Water uptake & $\mathrm{NU}=8.38^{*} \mathrm{WU}$ & 0.67 \\
Leaf area index & $\mathrm{NU}=-2.29 *(\mathrm{LAI})^{2}+4.11 *(\mathrm{LAI})-0.19$ & 0.74 \\
Vapor pressure deficit & $\mathrm{NU}=-0.52 *(\mathrm{VPD})+0.57$ & 0.08 \\
\hline
\end{tabular}

Table 5. Simple correlation between nitrogen uptake $\left(\mathrm{mmol} \cdot \mathrm{d}^{-1} / \mathrm{plant}\right)$ and temperature $\left(\mathrm{T} ;{ }^{\circ} \mathrm{C}\right)$, global radiation $\left(\mathrm{Rg} ; \mathrm{MJ} \cdot \mathrm{m}^{-2} \cdot \mathrm{d}^{-1}\right)$, water uptake $\left(\mathrm{WU} ; \mathrm{L} \cdot \mathrm{d}^{-1} /\right.$ plant $)$, vapor pressure deficit $(\mathrm{VPD} ; \mathrm{kPa})$, and leaf area index $\left(\mathrm{m}^{2} \cdot \mathrm{m}^{-2}\right)$ in TB and TC.

\begin{tabular}{llc}
\hline Parameters & Correlation model & Correlation coefficient $\left(\mathrm{R}^{2}\right)$ \\
\hline Temperature & $\mathrm{NU}=-0.10^{*} \mathrm{~T}+1.34$ & 0.20 \\
Radiation & $\mathrm{NU}=0.32 * \mathrm{Rg}+0.26$ & 0.71 \\
Water uptake & $\mathrm{NU}=12.17 * \mathrm{WU}$ & 0.66 \\
Leaf area index & $\mathrm{NU}=0.42 *(\mathrm{LAI})+1.09$ & 0.23 \\
Vapor pressure deficit & $\mathrm{NU}=0.66 *(\mathrm{VPD})+1.57$ & 0.08 \\
\hline
\end{tabular}

Table 6. Multiple regressions between nitrogen uptake and climatic and growth parameter for TA and TB and TC treatments.

\begin{tabular}{|c|c|c|c|}
\hline & $\begin{array}{c}\mathrm{N} \text { uptake } \\
\text { model }\end{array}$ & $\mathrm{R}^{2}$ & $\begin{array}{c}\text { Covariance } \\
\text { between } \\
\text { independent } \\
\text { variables }\end{array}$ \\
\hline \multirow[t]{4}{*}{$\overline{\mathrm{TA}}$} & $\mathrm{f}(\mathrm{LAI}, \mathrm{T})$ & 0.79 & -0.79 \\
\hline & f(LAI,WU) & 0.77 & -0.81 \\
\hline & $\mathrm{f}(\mathrm{LAI}, \mathrm{VPD})^{\mathrm{z}}$ & 0.82 & 0.01 \\
\hline & f(LAI,Rg) & 0.79 & -0.11 \\
\hline \multirow[t]{4}{*}{$\mathrm{TB}$ and $\mathrm{TC}$} & $\mathrm{f}(\mathrm{Rg}, \mathrm{T})$ & 0.71 & -0.19 \\
\hline & $\mathrm{f}(\mathrm{Rg}, \mathrm{WU})$ & 0.69 & 0.09 \\
\hline & f(Rg,VPD) & 0.71 & 0.26 \\
\hline & $\mathrm{f}(\mathrm{Rg}, \mathrm{LAI})$ & 0.71 & 0.19 \\
\hline
\end{tabular}

${ }^{\mathrm{z}}$ Where $\mathrm{f}(\mathrm{LAI}, \mathrm{VPD})$ is $0.99 * \mathrm{f}(\mathrm{LAI})-0.51 * \mathrm{VPD}$ 0.23 and $\mathrm{f}(\mathrm{LAI})$ is $-2.29 *(\mathrm{LAI})^{2}+4.11 * \mathrm{LAI}-0.19$ (Table 4). Coefficients are significant at the $0.5 \%$ level.

correlation. High radiation and VPD values cause high transpiration rates, which have a direct effect on water and nutrient uptake (Medrano et al., 2004). Transpiration is usually accepted as the driving force for the long-distance transport of nutrients through xylem vessels of higher plants (Amor and Marcelis, 2005). Whether transpiration affects uptake rate elements depends on plant age, time of day, external concentration, and type of mineral element (Marschner, 1995). Mineral elements taken up in an active way are less affected by transpiration stream. N uptake and LAI present a polynomial correlation $\left(\mathrm{R}^{2}=0.74\right)$; similar results were found by Vidal et al. (1999). These authors obtained a positive correlation in spring wheat crops during the booting period, but not at the end of tilling. LAI is one of the most important physiological parameters and has an effect on crop productivity, because it directly quantifies the plant's canopy structure, being therefore closely related to a variety of canopy processes such as photosynthesis and respiration. These two canopy processes are related to nutrient supply (Mandal and Sinha, 2004). For ammonium treatments, the most correlated environmental parameters were radiation $\left(\mathrm{R}^{2}=0.71\right)$ and water uptake $\left(\mathrm{R}^{2}=0.66\right)$ (Table 5). Light does not have a direct effect on mineral uptake, but high amounts of light increase carbohydrate provision as well as transpiration and respiration valuation, which provoke an intensified uptake (Mazliak, 1976). This high correlation with radiation was also found by Zerche et al. (2002) and Brun and Chazelle (1996).

To improve the model, a multiple regression was carried out using $f(L A I)$ in nitrate treatment and $f(R g)$ in ammonium treatments. The inclusion of VPD in the nitrate uptake model improves its determination coefficient. Nevertheless, no other variable would improve the ammonium uptake model (Table 6).

Empirical models of nitrogen uptake concentration. In a practical way, to calculate nutrient concentrations in nutrient solution for greenhouse cultures, fluctuations in water uptake together with fluctuating nutrient demand must be considered (Zerche, 2000). However, Sonneveld and Voogt (1990) consider that nitrogen uptake concentration has in TA. in TB and TC. no physiological basis, because nutrient and water uptakes are independent processes with different dynamics; photosynthesis is curvilinear regarding radiation input, whereas transpiration shows a mainly linear relationship with radiation (Sonneveld, 2002). In this case, there was a high correlation between nitrogen uptake and water consumption (Fig. 3) as observed by Kläring et al. (1997) with potassium. For nitrate treatment, an $\mathrm{N}$ uptake concentration value of $8.38 \mathrm{mmol} \cdot \mathrm{L}^{-1}\left(\mathrm{R}^{2}=\right.$ $0.67)$ was obtained and another value of $12.17 \mathrm{mmol} \cdot \mathrm{L}^{-1}\left(\mathrm{R}^{2}=0.66\right)$ for treatments with ammonium. Because uptake concentration varies considerably during the day, and between days, depending on prevailing environmental conditions (Adams, 2002), a simple regression analysis was carried out between uptake concentration in TA, TB, and TC with regard to air temperature, VPD, Rg, and LAI as basic factors that may affect the environment and growth (Tables 7 and 8 ). In $\mathrm{N}^{-\mathrm{NO}_{3}}{ }^{-}$treatment, temperature, VPD, and LAI were the most correlated parameters with $\mathrm{N}$ uptake concentration (Table 7), but $\mathrm{R}^{2}$ was always low $(P<$ $0.05)$. For ammonium treatments, the values of $\mathrm{R}^{2}$ were lower than 0.11 in each case. (Table 8).

Comparison between the different models studied. This study proposes two models for the estimation of the $\mathrm{N}$ uptake concentration depending on the $\mathrm{N}$ form applied: 1) a fixed concentration value obtained by the slope of the linear correlation between $\mathrm{N}$ uptake and water uptake, and 2) a relation between the $\mathrm{N}$ uptake estimated through the model (LAI and VPD were used in $\mathrm{N}-\mathrm{NO}_{3}{ }^{-}$treatment and radiation in $\mathrm{N}_{-} \mathrm{NH}_{4}{ }^{+}$treatments) and the experimental water uptake. A $1 \%$ error and a SE deviation of the two methods were calculated (Table 9). The use of a unique nitrogen uptake concentration is less precise, and the second model is closer to experimental values but with a higher SD in nitrate treatment. These results show the influence of the $\mathrm{N}$ form applied in the parameter, which could affect $N$ uptake. Similarly, research with excised rice roots show that uptake of $\mathrm{NO}_{3}{ }^{-} \mathrm{N}$ depends considerably on temperature; however, such clearcut effects were

Table 7. Correlation between nitrogen uptake concentration (NUC; mmol $\cdot \mathrm{L}^{-1}$ ) and temperature $\left(\mathrm{T} ;{ }^{\circ} \mathrm{C}\right)$, global radiation $\left(\mathrm{Rg} ; \mathrm{MJ} \cdot \mathrm{m}^{-2} \cdot \mathrm{d}^{-1}\right)$, deficit vapor pressure $(\mathrm{DPV} ; \mathrm{kPa})$, and leaf area index $\left(\mathrm{LAI} ; \mathrm{m}^{2} \cdot \mathrm{m}^{-2}\right)$

\begin{tabular}{llc}
\hline Parameters & \multicolumn{1}{c}{ Correlation } & Correlation coefficient $\left(\mathrm{R}^{2}\right)$ \\
\hline Temperature & $\mathrm{NUC}=0.52 * \mathrm{~T}-5.09$ & 0.44 \\
Radiation & $\mathrm{NUC}=0.83 * \mathrm{Rg}+4.45$ & 0.14 \\
Leaf area index & $\mathrm{NUC}=-11.74 *(\mathrm{LAI})^{2}+20.03 * \mathrm{LAI}+2.81$ & 0.42 \\
Vapor pressure deficit & $\mathrm{NUC}=27.26 *(\mathrm{VPD})^{2}+25.61 * \mathrm{VPD}+11.48$ & 0.53 \\
\hline
\end{tabular}

Table 8. Correlation between nitrogen uptake concentration (NUC; mmol $\left.\cdot \mathrm{L}^{-1}\right)$ and temperature $\left(\mathrm{T} ;{ }^{\circ} \mathrm{C}\right)$, global radiation $\left(\mathrm{Rg} ; \mathrm{MJ} \cdot \mathrm{m}^{-2} \cdot \mathrm{d}^{-1}\right)$, vapor pressure deficit (VPD; $\left.\mathrm{kPa}\right)$, and leaf area index $\left(\mathrm{LAI} ; \mathrm{m}^{2} \cdot \mathrm{m}^{-2}\right)$

\begin{tabular}{lcc}
\hline Parameters & \multicolumn{1}{c}{ Correlation } & Correlation coefficient $\left(\mathrm{R}^{2}\right)$ \\
\hline Temperature & $\mathrm{NUC}=-0.67 * \mathrm{~T}+30.53$ & 0.11 \\
Radiation & $\mathrm{NUC}=1.11 * \mathrm{Rg}+9.97$ & 0.04 \\
Leaf Area Index & $\mathrm{NUC}=-4.90 * \mathrm{LAI}+17.07$ & 0.10 \\
Vapor pressure deficit & $\mathrm{NUC}=6.60 * \mathrm{VPD}+17.15$ & 0.05 \\
\hline
\end{tabular}


Table 9. Error in one percentage and SD of the different $\mathrm{N}$ uptake concentration models.

\begin{tabular}{lrrrrr}
\hline & \multicolumn{2}{c}{ TA } & & \multicolumn{2}{c}{ TB and TC } \\
\cline { 2 - 3 } \cline { 5 - 6 } & Fixed & & & Fixed & \\
& value & Model & & value & Model \\
\hline Error $(1 \%)$ & -0.21 & -0.19 & & -0.08 & -0.06 \\
SD & 0.73 & 0.70 & & 0.20 & 0.19 \\
\hline
\end{tabular}

not observed with $\mathrm{NH}_{4}{ }^{+}-\mathrm{N}$ (Sasakawa and Yamamoto, 1978).

\section{Conclusion}

The sources of nitrogen applied generate important modifications in $\mathrm{pH}$ and nitrate and ammonium concentrations in nutritive solution during the recirculating solution. These changes must be known to optimize the management of these systems. Supply of $\mathrm{N}_{-} \mathrm{NO}_{3}^{-}$does not generate abrupt variations of the different nutritional parameters. However, the application of $\mathrm{N}-\mathrm{NH}_{4}{ }^{+}$generates acidification of the recirculating solution, an increase in the concentration of $\mathrm{N}^{-} \mathrm{NO}_{3}{ }^{-}$, and a decrease in the concentration of $\mathrm{N}^{-} \mathrm{NH}_{4}^{+}$, which is more significant in summer. This decrease is mainly the result of the nitrification process and higher nitrogen uptake rates in $\mathrm{N}^{-\mathrm{NH}_{4}}{ }^{+}$ or $\mathrm{N}-\mathrm{NO}_{3}{ }^{-}+\mathrm{NH}_{4}{ }^{+}$treatments. This study also indicates the possibility of predicting $\mathrm{N}$ uptake rate and $\mathrm{N}$ uptake concentration using the proposed models. From a practical point of view, this modeling would allow the design of nutritive solutions during the cultivation of Dieffenbachia amoena 'Tropic Snow', which may also be used for other ornamental plants, improving their nitrogen use efficiency, and could prevent salt accumulation or depletion in nutrient solutions in closed systems.

\section{Literature Cited}

Adams, P. 2002. Nutritional controls in hydroponics, p. 211-261. In: Savvas, D. and H. Passam (eds.). Hidroponic production of vegetables and ornamentals. Embryo Publ. Press, Athens, Greece.

Amor, F.M. and L.F.M. Marcelis. 2005. Regulation of growth and nutrient uptake under different transpiration regimes. Acta Hort. 697:523-528.

Bar-Tal, A., B. Aloni, L. Karni, and R. Rosenberg. 2001. Nitrogen nutrition of greenhouse pepper. II. Effects of nitrogen concentration and $\mathrm{NO}_{3}: \mathrm{NH}_{4}$ ratio on growth, transpiration and nutrient uptake. HortScience 36:1252-1259.

Bernstein, N., M. Ioffe, M. Bruner, Y. Nishri, G. Luria, I. Dori, E. Matan, S. Philosoph-Hadas, N. Umiel, and A. Hagiladi. 2005. Effects of supplied nitrogen form and quality of Ranunculus asiaticus flowers. HortScience 40:1879-1886.

Brun, R. and L. Chazelle. 1996. Water and nitrate absorption kinetics in the Nychthemeral cycle of rose grown in the greenhouse using a recirculating solution. J. Plant Nutr. 19:839-867.

Cabrera, R.I., R.Y. Evans, and J.L. Paul. 1995. Cyclic nitrogen uptake by greenhouse roses. Scientia Hort. 63:57-66.
Canavos, G.C. 1988. Probabilidad y estadística. Aplicaciones y métodos. McGraw Hill, Madrid.

Economakis, C.D. and L. Krulj. 2002. Water and nutrient uptake by strawberry plants grown with the nutrient film technique (NFT) under different minimum solution temperatures. Acta Hort. 579:405-410.

Epstein, E. and A.J. Bloom. 2004. Mineral nutrition of plants: Principles and perspectives. 2nd ed. Sinauer, Sunderland, MA.

Feller, C. and M. Fink. 2002. Nitrogen uptake by table beet-validation of a model. J. Amer. Soc. Hort. Sci. 127:1013-1017.

Hahne, K.S. and U.K. Schuch. 2006. Nitrogen form and concentration affect nitrogen leaching and seedling growth of Prosopis velutina. HortScience 41:239-243.

Jiménez, S. 2001. Estudio nutricional de la Dieffenbachia amoena 'Tropic Snow'. Almería Univ., Spain. PhD Diss.

Jiménez, S. and M.T. Lao. 2005. Influence of nitrogen form on the quality of Dieffenbachia amoena 'Tropic Snow'. HortScience 40:386390.

Jiménez, S., M. Pérez, B.M. Plaza, R. Salinas, and M.T. Lao. 2007. Empirical models of phosphorus uptake under different nitrogen sources in Dieffenbachia amoena 'Tropic Snow'. HortScience 42:1-5.

Kim, T., H.A. Mills, and H.Y. Wetzstein. 2002 Studies of effects of nitrogen form on growth, development, and nutrient uptake in pecan. J. Plant Nutr. 25:497-508.

Kläring, H.P., D. Schwarz, and A. Heissner. 1997. Control of nutrient solution concentration in tomato crop using models of photosynthesis and transpiration: A simulation study. Acta Hort. 450:329-334.

Le Bot, J., S. Adamowicz, and P. Robin. 1998. Modelling plant nutrition of horticultural crops: A review. Scientia Hort. 74:47-82.

Mandal, K.G. and A.C. Sinha. 2004. Nutrient management effects on light interception, photosynthesis, growth, dry-matter production and yield of Indian mustard (Brassica juncea). J. Agron. Crop Sci. 190:119-129.

Marschner, H. 1995. Mineral nutrition of higher plants. 2nd ed. Academic, London.

Martinez, P.F., D. Roca, S. Martinez, R. Suay, E. Carbonell, and J. Perez. 2004. Nitrate uptake kinetics by a rose crop in a closed hydroponics system. Acta Hort. 659:605-612.

Mazliak, P. 1976. Fisiología Vegetal. Nutrición y metabolismo. Colección Métodos. Ediciones Omega, S.A., Barcelona.

Medrano, E., P. Lorenzo, M.C. Sánchez-Guerrero, M.L. García, I. Caparrós, G. Coelho, and M. Jiménez. 2004. Water and nutrient use efficiency of a tomato crop as affected by two refrigeration methods: External mobile shading and fog systems. Acta Hort. 697:463-467.

Mengel, K. and E.A. Kirkby. 2001. Principles of plant nutrition. 5th ed. Intl. Potash Inst., Bern, Switzerland.

Ministry of Agriculture and Fishing. 1994. Métodos Oficiales de Análisis. Tomo III. Secretaría General Técnica, Madrid.

Pardossi, A., F. Falossi, F. Malorgio, L. Incrocci, and G. Bellocchi. 2004. Empirical models of macronutrient uptake in melon plants grown in recirculating nutrient solution culture. J. Plant Nutr. 27:1261-1280.

Phiri, S., I.M. Rao, E. Barrios, and B.R. Singh. 2003. Plant growth, mycorrhizal association, nutrient uptake and phosphorus dynamics in a volcanic-ash soil in Colombia as affected by the establishment of Tithonia diversifolia. J. of Sustainable Agr. 21:43-61.

Rengel, Z. 1993. Mechanistic simulation models of nutrient uptake: A review. Plant Soil 152:161173.

Rincón, L., A. Pérez, A. Abadía, and C. Pellicer. 2004. Tomato yield in coconut substrate water and nutrient uptake. Acta Hort. 697:112117.

Roca, D., P.F. Martinez, R. Suay, and S. Martinez. 2003. Nitrate and water uptake rates on a short term basis by a rose soilless crop under greenhouse. Acta Hort. 614:181-187.

Sasakawa, H. and Y. Yamamoto. 1978. Comparison of the uptake of nitrate and ammonium by rice seedlings influences of light, temperature, oxygen concentration, exogenous sucrose, and metabolic inhibitors. Plant Physiol. 62:665-669.

Savvas, D., V. Karagianni, A. Kotsiras, V. Demopoulos, I. Karkamisi, and P. Pakou. 2003. Interaction between ammonium and $\mathrm{pH}$ of the nutrient solution supplied to gerbera (Gerbera Jamesonii) grown in pumice. Plant Soil 254:393-402.

Savvas, D., H.C. Passam, C. Olympios, E. Nasi, E. Moustaka, N. Mantzos, and P. Barouchas. 2006. Effects of ammonium nitrogen on lettuce grown on pumice in a closed hydroponic system. HortScience 41:1667-1673.

Sonneveld, C. 2002. Composition of nutrient solutions, p. 179-210. In: Savvas, D. and H.C. Passam (eds.). Hydroponic production of vegetables and ornamentals. Embryo Publisher, Press, Athens, Greece.

Sonneveld, C. and W. Voogt. 1990. Response of tomatoes (Lycopersicum sculentum) to an unequal distribution of nutrients in the root environment. Plant Soil 124:251-256.

Stratton, M.L., G.L. Good, and A.V. Barker. 2001. The effects of nitrogen source and concentration of the growth and mineral composition of privet. J. Plant Nutr. 24:1745-1772.

Terabayashi, S., I. Muramatsu, S. Tokutani, M. Ando, F. Kitagawa, T. Shigemori, S. Date, and Y. Fujime. 2004. Relationship between the weekly nutrient uptake rate during fruiting stage and fruit weight of tomato (Lycopersicon esculentum Mill.) grown hydroponically. J. Japanese Soc. Hort. Sci. 73:324-329.

Van Beusichem, M.L., E.A. Kirkby, and R. Baas. 1988. Influence of nitrate and ammonium nutrition on the uptake, assimilation, and distribution of nutrients in Ricinus communis. Plant Physiol. 86:914-921.

Vidal, I., L. Longeri, and J.M. Hétier. 1999. Nitrogen uptake and chlorophyll meter measurements in Spring Wheat. Nutrient Cycling in Agroecosystems 55:1-6.

Wang, G., Ch. Li, and F. Zhang. 2003. Effects of different nitrogen forms and combination with foliar spraying with 6-benzylaminopurine on growth, transpiration, and water and potassium uptake and flow in tobacco. Plant Soil 256: $169-178$

Wen, X., H. Ikeda, and M. Oda. 2000. The absorption, translocation, and assimilation of urea nitrate or ammonium in tomato plant at different plant growth stages in hydroponic culture. Scientia Hort. 84:275-283.

Zerche, S. 2000. Nitrogen demand of cut Chrysanthemums in relation to shoot height and solar radiation. Acta Hort. 511:99-106.

Zerche, S., U. Druege, and R. Kadner. 2002 Models for nitrogen uptake and related quality assurance in horticultural and agronomic crop production. Acta Hort. 593:243-248. 